\title{
Botanical characterisation, drug indications and sustainability status of traditional oral powdered herbal formulations in Ogbomoso, Nigeria
}

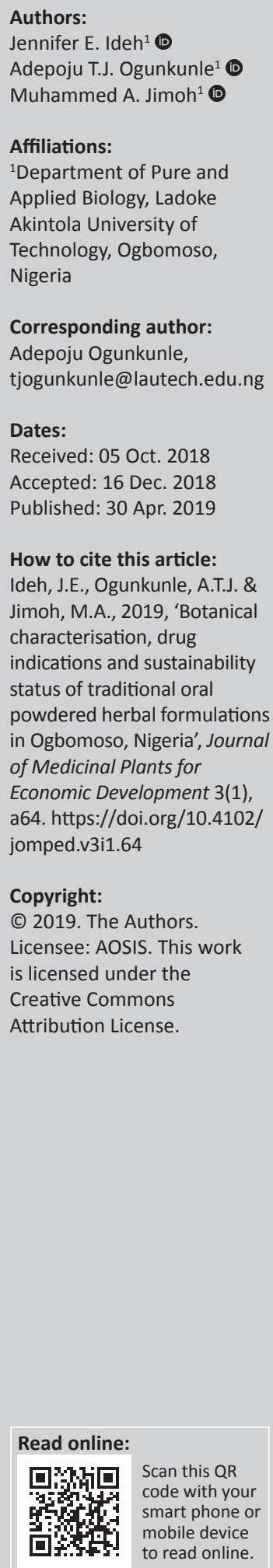

Background: The foremost requirements in quality control of a herbal drug are its identity and purity. In addition, information is necessary on whether continual exploitation of medicinal herbs for traditional oral powdered herbal formulations (TOPHFs) in Ogbomoso, Nigeria, is sustainable.

Aim: To botanically characterise and ethno-medicinally document the health indications of TOPHFs manufactured in Ogbomoso, as well as to examine the sustainability status of the drugs.

Setting: Ogbomoso, Nigeria.

Methods: Fifteen manufacturers of TOPHFs provided information on the botanical constituents and recipes of their products, the sources of raw material herbs, and types of health conditions treated with the drugs. Sustainability status of the drugs was quantified as relative percentage of the three choices of sources of raw material herbs available to the manufacturers and in terms of conservation status of the plant species as recorded by the International Union for Conservation of Nature.

Results: Fifty-five medicinal plant species from 33 angiosperm families were used by traditional herbal medical practitioners to produce 68 TOPHFs that are indicated for treating 17 different health conditions. The sources of raw material herbs, in relative terms, were purchased from herbal markets $(43.8 \%)$, collected from the wild (28.1\%) and cultivated (28.1\%). Most of the herbs can be sustainably harvested and only 3 (i.e. 5.5\%) of the 55 plant species (i.e. Lophira alata Banks ex Gaertn., Khaya senegalensis A. Juss. and Garcinia kola Heckel) are under threatened (vulnerable) species.

Conclusion: Production of TOPHFs in Ogbomoso is sustainable with minimal injury on the natural flora.

Keywords: Traditional oral powdered herbal formulations; Sustainable exploitation of medicinal herbs; Ethno-Medicine; Forest conservation; Ethno-Botany.

\section{Introduction}

The Medical and Dental Practitioners' (Amendment) Decree number 78 promulgated by the Government of Nigeria on 30 September 1992 placed traditional and alternative medicine side by side with orthodox medicine (ABFR \& CO 1996). However, a key obstacle to the acceptance of alternative medicine in certain parts of the world lies in the lack of documentation and stringent quality control (Prasad et al. 2012). African herbal products have particularly been called to question on account of adulteration, substitution, contamination, misidentification of ingredients, lack of standardisation, incorrect preparation and/or dosage, inappropriate labelling and/or advertisement (Lau, Woo \& Koh 2003; World Health Organization 2003). For these reasons, herbal products from Africa have not enjoyed worldwide acceptability compared to those from other countries such as India and China (Patwardhan et al. 2005).

The World Health Organization (World Health Organization 2002) refers to quality of herbal drugs on the basis of their reproducible efficacy and safety, while Bauer (Bauer 1998) identifies quality criteria in terms of the scientific definition of the raw materials. Therefore, standardisation and quality control of herbal formulations seem to hinge mainly on their identity and purity. To that extent, correct identification and quality assurance of the starting materials is an essential prerequisite to ensure reproducible quality of herbal medicine, which will contribute to its safety and efficacy 
(Kadam et al. 2012). Although many believe that it is difficult to establish comprehensive quality for herbal drugs because of professional secrecy of traditional herbal medical practitioners (THMPs), this challenge has been shown to be surmountable (Obu 2015). The raw medicinal herbs serving as the starting materials for traditional oral powdered herbal formulations (TOPHFs) in Ogbomoso are regarded as 'active ingredients' for these drugs (World Health Organization 2000), and their enumeration formed one of the focal points for this study.

There is ample evidence to show increasing human dependence on herbal drugs for primary healthcare (World Health Organization 1998), but we hardly seek to know where the herbs we use come from. One may wonder why we need to be mindful of the source of medicinal herbs, but the herbs we take as medicine are inextricably connected to the processes that produce them. In fact, we cannot be healthy unless our environment is healthy. Therefore, if we choose to use plants as our medicine, we become accountable for the vegetation or environment that produced the plants. This is the pattern of thinking in sustainable herbal medicine (Medicine Hunter 2012; Pesic 2015).

The strategies for ensuring sustainability of medicinal plants production have been highlighted to include in situ and ex situ conservation efforts, controlled cultivation and sustainable harvesting, among others (Chen et al. 2016; World Health Organization 2003). For these strategies to succeed in a country, the political will is the first requirement. Presently, there is no government policy in place to ensure the sustainability of traditional medicine and the protection of the environment in Nigeria (Osunderu 2009). However, the literature has it that traditional healers in Ogbomoso prepare and market various herbal preparations used for different types of ill health conditions. Among these are the TOPHFs used by different categories of residents of the city (Ogunkunle \& Ashiru 2011). There is no information on whether continual exploitation of medicinal plants for TOPHFs in Ogbomoso is sustainable or not. This gap formed another area of consideration in this study.

Against the aforestated background, the objectives of this study were to botanically characterise and ethno-medicinally document the health indications of TOPHFs in Ogbomoso, as well as to examine the conservation status of the medicinal plants alongside the cultivation efforts being made by the THMPs.

\section{Materials and methods}

This study was conducted in 2014 in Ogbomoso, Nigeria, located around $8.1333^{\prime} \mathrm{N}$ latitude and $4.2567^{\prime} \mathrm{E}$ longitude. The target population consisted of the THMPs in the study area who produced, sold and provided healing services with TOPHFs. Seventeen THMPs were selected using stratified sampling technique, during which each of the five local government areas (LGAs) was taken as a stratum. Fifteen of the THMPs were eventually found suitable for inclusion, to whom a questionnaire was administered or used as an interview schedule.
Section A of the questionnaire sought the herbal healers' socio-demographic data with 11 questions, while Section B, with 9 questions, was used to gather information on the types of TOPHFs they manufactured and sold, their botanical constituents and sources of the herbs used, the ailments they were meant to treat, and details of preparation of the drugs. In seeking information about the sources of raw herbal materials, the THMPs were supplied with a list of possible sources (i.e. purchase, collection from the wild, cultivation, etc.) and each of them was asked to tick as many of the options as applicable to him or her. Each of these multiple choices was considered as an independent variable across the 15 participants and counted. Thereafter, a summation of the counts for the 3 alternatives selected was obtained and equated to $100 \%$, from which the relative percentage of each choice was computed. The relative percentage value obtained for cultivation of the required herbal materials was taken as sustainability index for TOPHFs in the study area.

Information on the conservation status or population dynamics of each of the plant species used by the TOPHF manufacturers was obtained by cross-checking its name against the red list of threatened plant species compiled by the International Union for Conservation of Nature (IUCN 2017). The proportion of the species in the threatened category, taken alongside conservation efforts by the THMPs, was used to project whether manufacturing of TOPHFs in Ogbomoso was sustainable.

Codes (A, B, C, D, etc.) were assigned to the THMPs for anonymity purpose, while their products were labelled with reference to the indications (i.e. health conditions that they treat) of the drugs they produced. In doing this, each health condition was first given a short code of five alphabets, which was then used as a hyphenated prefix to the anonymity code of its manufacturer, such as MALAR-B (i.e. malaria drug from healer B) , PILES-F (i.e. drug for piles from healer F) and TYPHO-E (i.e. drug for typhoid from healer E) (see Table 1).

\section{Results}

\section{Information about the traditional herbal medical practitioners contacted and their activities}

Out of the 17 THMPs initially recruited in the study, 13 (i.e. $76.5 \%$ ) were men and 4 (i.e. $23.5 \%$ ) were women; 10 of them (about $59 \%$ ) were over 50 years of age. The majority of the healers $(70 \%)$ had only primary and/or secondary education, but up to $65 \%$ of them had practiced in the profession for more than 30 years. Historically, these people came into the profession by descent (being their family trade), while few others either combined some form of training with this option or depended on their natural gifts or talents to become traditional healers. The THMPs updated their knowledge of medical practice through a wide range of choices, such as by intuition (35.3\%), attendance at health talks or meetings (11.0\%) and electronic media (5.9\%), while $47.8 \%$ of them adopted various forms of a combination of these and other choices. Of the 17 THMPs contacted, 15 produced, sold and applied TOPHFs against 17 different types of health conditions, 
TABLE 1: Information about the traditional herbal healers who participated in the study.

\begin{tabular}{|c|c|c|c|}
\hline \multirow[t]{2}{*}{ Variable } & \multicolumn{3}{|c|}{ Number of participants } \\
\hline & Male & Female & Total $(N=17)$ \\
\hline \multicolumn{4}{|l|}{ Age (years) } \\
\hline $31-40$ & 4 & 0 & 4 \\
\hline $41-50$ & 2 & 1 & 3 \\
\hline$>50$ & 7 & 3 & 10 \\
\hline \multicolumn{4}{|l|}{ Formal education } \\
\hline None & 0 & 2 & 2 \\
\hline Primary & 7 & 1 & 8 \\
\hline Secondary & 3 & 1 & 4 \\
\hline OND or NCE & 1 & 1 & 2 \\
\hline HND or Degree & 1 & 0 & 1 \\
\hline \multicolumn{4}{|l|}{ Experience (years) } \\
\hline$<10$ & 2 & 0 & 2 \\
\hline 10-20 & 1 & 1 & 2 \\
\hline $21-30$ & 1 & 1 & 2 \\
\hline$>30$ & 9 & 2 & 11 \\
\hline \multicolumn{4}{|l|}{ Professional history } \\
\hline By descent & 11 & 4 & 15 \\
\hline By training & 0 & 0 & 0 \\
\hline Both by descent and training & 1 & 0 & 1 \\
\hline Others $\dagger$ & 1 & 0 & 1 \\
\hline \multicolumn{4}{|l|}{ Manufacturer of powdered herbs } \\
\hline Yestit & 11 & 4 & 15 \\
\hline No & 2 & 0 & 2 \\
\hline \multicolumn{4}{|l|}{ Update of knowledge in medical practice } \\
\hline By intuition (A) & 5 & 1 & 6 \\
\hline Attendance of meetings or health talks (B) & 2 & 0 & 2 \\
\hline Electronic media (C) & 1 & 0 & 1 \\
\hline Internet (D) & 0 & 0 & 0 \\
\hline$A$ and $B$ & 2 & 3 & 5 \\
\hline$A, B$ and $C$ & 1 & 0 & 1 \\
\hline$A, B, C$ and $D$ & 2 & 0 & 2 \\
\hline
\end{tabular}

OND, Ordinary National Diploma; NCE, Nigeria Certificate in Education; HND, Higher Nationa Diploma.

$\dagger$, Talent from God.

$\dagger$, Of the 17 herbal healers, 15 produced powdered herbal formulations for oral use and their residential homes doubled as factories, with none of them having evidence of registration of their products with National Food and Drug Administration and Control.

including maintenance of general body homeostasis and the management of some dreaded diseases, such as high blood pressure and diabetes. All of the 15 THMPs (100\%) produced oral powdered drugs for malaria therapy, and also sizable proportions of them $(6.7 \%$ in each case) produced powdered drugs for female infertility, onchocerciasis, diabetes, stomach ulcers and yellow fever (Table 2).

\section{Medicinal plants used by traditional herbal medical practitioners in Ogbomoso to produce traditional oral powdered herbal formulations}

A total of 55 medicinal plant species from 33 angiosperm families were listed by the THMPs as constituents of TOPHFs in Ogbomoso, Nigeria. Plants of the families Fabaceae, Cucurbitaceeae and Euphorbiaceae were most widely used, followed by those of Amaryllidaceae, Annonaceae, Apocynaceae, Combretaceae, Rutacecae, Solanaceae and Zingiberaceae. Members of the other 23 families were seldom used by the THMPs (Tables 3-13). The plant parts used as herbs include fruits, seeds, leaves, stem barks, flowers, roots
TABLE 2: List of health conditions indicated for traditional oral powdered herbal formulations manufactured and marketed in Ogbomoso, Nigeria.

\begin{tabular}{llc}
\hline Number & Health condition or type of powdered herb & $\begin{array}{c}\text { Number of } \\
\text { manufacturers }(\boldsymbol{N}=\mathbf{1 5})\end{array}$ \\
\hline 1 & Arthritis and rheumatism & 2 \\
2 & Back and waist pain & 2 \\
3 & Bareness or female infertility & 1 \\
4 & Blood enricher or enhancer & 4 \\
\hline 5 & Blood purifier or thinner & 6 \\
\hline 6 & Body itch or onchocerciasis & 1 \\
7 & Convulsion & 2 \\
8 & Diabetes & 1 \\
9 & Male erectile dysfunction & 2 \\
10 & Gonorrhoea & 2 \\
\hline 11 & High blood pressure & 8 \\
12 & Jaundice or anaemia & 6 \\
13 & Malaria & 15 \\
14 & Piles & 14 \\
15 & Typhoid & 11 \\
16 & Ulcer (stomach, duodenum, peptic) & 1 \\
17 & Yellow fever & 1 \\
\hline & & \\
\hline
\end{tabular}

TABLE 3: Names of plants and their parts used for the formulation of traditional oral powdered herbal formulations for the treatment of arthritis or rheumatism in Ogbomoso, Nigeria.

\begin{tabular}{llll}
\hline Number & Plant species & Family name & Part(s) used \\
\hline 1 & Elais guinensis Jacq. & Arecaceae & Dry kernel shell \\
2 & Allium sativum L. & Amaryllidaceae & Leaf base or fruit \\
3 & Xylopia aethiopica (Dunel) A. Rich. & Annonaceae & Fruit with seeds \\
4 & Aframomum melegueta K. Schum. & Zingiberaceae & Fruit \\
5 & Garcinia kola Heckel & Clusiaceae & Seeds \\
6 & Allium cepa L. & Amaryllidaceae & Leaves \\
\hline
\end{tabular}

Herbal recipes for two powdered drugs: ARRHE-D (1, 2, 3, 4+ cow bone) and ARRHE-K $(5,6)$; suffix alphabets indicate the manufacturers' anonymity codes.

ARRHE, arthritis or rheumatism.

TABLE 4: Names of plants and their parts used for the formulation of traditional oral powdered herbal formulations for the treatment of back and waist pain in Ogbomoso, Nigeria

\begin{tabular}{llll}
\hline Number & Plant species & Family name & Part(s) used \\
\hline 1 & Piper guinense Schumach. & Piperaceae & Fruits \\
2 & Allium cepa L. & Amaryllidaceae & Leaves \\
3 & Xylopia aethiopica (Dunel) A. Rich. & Annonaceae & Fruit pods \\
4 & Capsicum frutescens L. & Solanaceae & Fruits \\
5 & Anthocleista djalonensis A. Chev. & Gentianaceae & Stem bark \\
6 & Morinda lucida Benth. & Rubiaceae & Stem bark \\
7 & Citrullus colocynthis (L.) Schrad. & Cucurbitaceae & Fruits \\
\hline
\end{tabular}

Herbal recipes for two powdered drugs: BAWAP-C $(1,3+$ potash) and BAWAP-O $(3,4,5,6,7)$. suffix alphabets indicate the manufacturers' anonymity codes.

BAWAP, back and waist pain.

TABLE 5: Names of plants and their parts for the formulation of traditional oral powdered herbal formulations used as blood enricher or enhancer in Ogbomoso, Nigeria.

\begin{tabular}{llll}
\hline Number & Plant species name & Family & Part(s) used \\
\hline 1 & Sorghum bicolor & Poaceae & Leaf sheath \\
2 & Maranthes polyandra Benth. & Chrysobalanaceae & Stem bark \\
3 & Alstonia boonei De Wild. & Apocynaceae & Stem bark \\
4 & Senna alata (L.) Roxb. & Fabaceae & Flowers \\
5 & S. alata (L.) Roxb. & Fabaceae & Root \\
6 & $\begin{array}{l}\text { Calyptrochilum christyanum } \\
\text { (Rchb. f.) Summerh }\end{array}$ & Orchidaceae & Leaves \\
\hline
\end{tabular}

Herbal recipes for four powdered drugs: BLENH-C ( 6 only), BLENH-F (1, $2+$ potash), BLENH-K $(3+$ table salt + potash) and BLENH-M $(4,5)$; suffix alphabets indicate the manufacturers' anonymity codes.

BLENH, blood enricher or enhancer. 
TABLE 6: Names of plants and their parts for the formulation of traditional ora powdered herbal formulations used as blood purifying or thinning drug in Ogbomoso, Nigeria.

\begin{tabular}{llll}
\hline Number & Plant species name & Family & Part(s) used \\
\hline 1 & $\begin{array}{l}\text { Alcohorneae laxiflora (Benth.) } \\
\text { Pax \& K. Hoffm. }\end{array}$ & Euphorbiaceae & Leaves \\
2 & $\begin{array}{l}\text { Tetrapleura tetraptera } \\
\text { (Schumm. \& Thonn.)Taub. }\end{array}$ & Fabaceae & Fruits \\
3 & Allium cepa L. & Amaryllidaceae & Leaves \\
4 & $\begin{array}{l}\text { Harungana madagascariensis } \\
\text { Lam ex Poiret }\end{array}$ & Hypericaceae & Stem bark \\
5 & Capsicum frutescens L. & Solanaceae & Fruits \\
6 & Lophira alata Banks ex Gaertn. & Onchnaceae & Stem bark \\
7 & Khaya senegalensis A. Juss. & Meliaceae & Stem bark \\
8 & Allium sativum L. & Amaryllidaceae & Fruit or leaf base \\
9 & Zingiber officinale Roscoe & Zingiberaceae & Rhizome \\
10 & Xylopia aethiopica (Dunel) A. Rich. & Annonaceae & Fruit \\
\hline
\end{tabular}

Herbal recipes for six powdered drugs: BLPUR-B $(1,2,3)$, BLPUR-C $(4,5)$, BLPUR-E $(3,6,7,8,9)$ BLPUR-H (3, 5, + potash), BLPUR-I (5, 7, 10 + potash) and BLPUR-M (7, 10 + potash); suffix alphabets indicate the manufacturers' anonymity codes.

BLPUR, blood purifying or thinning drug.

TABLE 7: Names of plants and their parts used for the formulation of traditional oral powdered herbal formulations for the treatment of convulsion in Ogbomoso, Nigeria.

\begin{tabular}{llll}
\hline Number & Plant species name & Family & Part(s) used \\
\hline 1 & Nicotiana tabacum L. & Solanaceae & Leaves \\
2 & Khaya senegalensis A. Juss. & Meliaceae & Stem bark \\
3 & Parkia biglobosa (Jacq.) R.Br ex G Don & Fabaceae & Fermented seeds \\
4 & Capsicum anuum L. & Solanaceae & Fruits \\
\hline
\end{tabular}

Herbal recipes for two powdered drugs: CONVU-B $(1+$ table salt) and CONVU-C $(2,3,4+$ table salt); suffix alphabets indicate the manufacturers' anonymity codes. CONVU, convulsion.

TABLE 8: Names of plants and their parts used for the formulation of traditional oral powdered herbal formulations for the treatment of male erectile dysfunction in Ogbomoso, Nigeria.

\begin{tabular}{llll}
\hline No. & Plant species name & Family & Part(s) used \\
\hline 1 & Sesamum indicum & Pedaliaceae & Leaves \\
2 & Abelmoscus esculentus (L.) Moench. & Malvaceae & Dried fruits \\
3 & Manihot esculenta Crantz & Euphorbiaceae & Root tuber \\
4 & Musa parasidiaca L. & Musaceae & Fruit \\
5 & Garcinia kola Heckel & Clusiaceae & Seed \\
\hline
\end{tabular}

MERDY, male erectile dysfunction.

Herbal recipes for two powdered drugs: MERDY-A $(1,2)$ and MERDY-D $(1,3,4,5)$; suffix alphabets indicate the manufacturers' anonymity codes.

TABLE 9: Names of plants and their parts used for the formulation of traditional oral powdered herbal formulations for the treatment of gonorrhoea in Ogbomoso, Nigeria.

\begin{tabular}{llll}
\hline No. & Plant species name & Family & Part(s) used \\
\hline 1 & Senna alata (L.) Roxb. & Fabaceae & Leaves \\
2 & Jatropha curcas L. & Euphorbiaceae & Fruits \\
3 & Xylopia aethiopica (Dunel) A. Rich. & Annonaceae & Fruits \\
4 & Adenopus breviflorus Benth. & Cucurbitaceae & Fruits \\
5 & Euphorbia lateriflora Sch. \& Thonn. & Euphorbiaceae & Leaves or stem \\
6 & Citrullus colocynthis (L.) Schrad. & Cucurbitaceae & Whole fruit \\
\hline
\end{tabular}

Herbal recipes for two powdered drugs: GONOR-B (1, 2+ sulphur) and GONOR-C ( 3, 4, 5, 6 + potash); suffix alphabets indicate the manufacturers' anonymity codes.

GONOR, gonorrhoea.

and rhizomes. Additional information obtained from the THMPs indicated the sources of raw material herbs available to them in relative terms as purchased from herbal markets or suppliers $(43.8 \%)$, collection from wild vegetation $(28.1 \%)$ and cultivation of some of the herbs for use $(28.1 \%)$.
TABLE 10: Names of plants and their parts used for the formulation of traditiona oral powdered herbal formulations for the treatment of high blood pressure in Ogbomoso, Nigeria.

\begin{tabular}{|c|c|c|c|}
\hline Number & Plant species name & Family & Part(s) used \\
\hline 1 & Citrus sinensis (L.) Osbeck & Rutaceae & Fruit rind or bark \\
\hline 2 & $\begin{array}{l}\text { Citrus aurantifolia } \\
\text { (Christ.) Swingle }\end{array}$ & Rutaceae & Whole fruits \\
\hline 3 & Aframomum melegueta K.Schum. & Zingiberaceae & Whole fruit \\
\hline 4 & Persea americana Miller & Lauraceae & Leaves \\
\hline 5 & $\begin{array}{l}\text { Parkia biglobosa (Jacq.) } \\
\text { R.Br ex G.Don }\end{array}$ & Fabaceae & Dried fermented seeds \\
\hline 6 & Xylopia aethopica (Dunel) A. Rich. & Annonaceae & Fruits \\
\hline 7 & Allium cepa $\mathrm{L}$. & Amaryllidaceae & Leaves \\
\hline 8 & Capsicum anuum L. & Solanaceae & Fruits \\
\hline 9 & $\begin{array}{l}\text { Parkia biglobosa (Jacq.) } \\
\text { R.Br ex G.Don }\end{array}$ & Fabaceae & Flowers \\
\hline 10 & Allium sativum $\mathrm{L}$. & Amaryllidaceae & Fruits or leaf base \\
\hline 11 & Zingiber officinale Roscoe & Zingiberaceae & Rhizome \\
\hline 12 & Enantia chlorantha Oliv. & Annonaceae & Stem bark \\
\hline 13 & $\begin{array}{l}\text { Calyptrochilum christyanum } \\
\text { (Rchb. f.) Summerh }\end{array}$ & Orchidaceae & Leaves \\
\hline 14 & Combretum mucronatum Thonn. & Combretaceae & Root \\
\hline 15 & $\begin{array}{l}\text { Curculigo pilosa } \\
\text { (Schum \& Thonn.) Engl. }\end{array}$ & Hypoxidaceae & Rhizome \\
\hline
\end{tabular}

Herbal recipes for eight powdered drugs: $\operatorname{HIGBP-A}(1,2,3), \operatorname{HIGBP-B}(4,5), \operatorname{HIGBP}-\mathrm{C}(6,7,8+$ table salt), HIGBP-D $(1,7,9,14)$, HIGBP-F $(5,10)$, HIGBP-I (15 only), HIGBP-M (11 + potash) and $\operatorname{HIGBP-N}(7,10,12)$; suffix alphabets indicate the manufacturers' anonymity codes.

HIGBP, high blood pressure.

TABLE 11: Names of plants and their parts used for the formulation of traditional oral powdered herbal formulations for the treatment of malaria fever in Ogbomoso, Nigeria.

\begin{tabular}{|c|c|c|c|}
\hline Number & Plant species name & Family & Part(s) used \\
\hline 1 & Senna accidentalis $\mathrm{L}$. & Fabaceae & Leaves \\
\hline 2 & Senna tora (L.) Roxb. & Fabaceae & Leaves \\
\hline 3 & Aframomum melegueta K. Schum. & Zingiberaceae & Whole fruit \\
\hline 4 & Morinda lucida Benth. & Rubiaceae & Leaves \\
\hline 5 & Capsicum frutescens $\mathrm{L}$. & Solanaceae & Fruits \\
\hline 6 & Alstonia boonei De Wild. & Apocynaceae & Leaves \\
\hline 7 & Alstonia boonei De Wild. & Apocynaceae & Stem bark \\
\hline 8 & Allium cepa $\mathrm{L}$. & Amaryllidaceae & Leaves \\
\hline 9 & Piper guinense Schumach. & Piperaceae & Fruits and leaves \\
\hline 10 & Carica papaya $\mathrm{L}$. & Caricaceae & Dried or fallen leaves \\
\hline 11 & Anthocleista djalonensis A. Chev. & Gentianaceae & Dried or fallen leaves \\
\hline 12 & Khaya senegalensis A. Juss. & Meliaceae & Stem bark \\
\hline 13 & $\begin{array}{l}\text { Anogeissus leiocarpus (DC) } \\
\text { Guill \& Perr. }\end{array}$ & Combretaceae & Stem bark \\
\hline 14 & Xylopia aethiopica (Dunel) A. Rich. & Annonaceae & Fruit pods \\
\hline 15 & Olax subscorpioidea Oliv. & Olacaceae & Root bark \\
\hline 16 & Securidaca longipedunculata Fresen. & Polygalaceae & Root bark \\
\hline 17 & $\begin{array}{l}\text { Senna podocarpa } \\
\text { (Guill. \& Perr.) Lock }\end{array}$ & Fabaceae & Leaves \\
\hline 18 & $\begin{array}{l}\text { Terminalia glauscecens } \\
\text { Planch. ex Benth. }\end{array}$ & Combretaceae & Root bark \\
\hline 19 & $\begin{array}{l}\text { Senna podocarpa } \\
\text { (Guill. \& Perr.) Lock }\end{array}$ & Fabaceae & Root bark \\
\hline 20 & $\begin{array}{l}\text { Eugenia aromaticum } \\
\text { (L.) Merr. \& L.M. Perry }\end{array}$ & Myrtaceae & Fruits or flowers \\
\hline
\end{tabular}

Herbal recipes for 15 powdered drugs: MALAR-A $(1,2,3)$, MALAR-B $(4,5,6,+$ table salt), MALAR-C $(5,7,8), \operatorname{MALAR}-\mathrm{D}(7,9,10+$ potash), MALAR-E $(5,12,13,14,15), \operatorname{MALAR}-\mathrm{F}(7,9,16,20)$ MALAR-G $(5,7,8), \operatorname{MALAR}-H(5,6,7$ + table salt), MALAR-I $(7,18), \operatorname{MALAR-J}(7+$ potash), MALAR-K $(7,14+$ potash), MALAR-L (17 only), MALAR-M(13, 14 +potash), MALAR-N $(5,8,12,18,19)$ and MALAR-O $(5,12,13,15)$; suffix alphabets indicate the manufacturers' anonymity codes.

MALAR, malaria feve.

A further scrutiny of the plant lists against the IUCN red list of threatened plants revealed that only 8 of the 55 plant species have been evaluated for their conservation status and population dynamics (IUCN, 2017). From these eight, 
TABLE 12: Names of plants and their parts used for the formulation of traditional oral powdered herbal formulations for the treatment of piles in Ogbomoso, Nigeria.

\begin{tabular}{llll}
\hline Number & Plant species name & Family & Part(s) used \\
\hline 1 & Lonchocarpus cyanescens Perkin & Fabaceae & Leaves \\
2 & Aframomom melegueta K.Schum. & Zingiberaceae & Whole fruit \\
3 & Senna alata (L.) Roxb. & Fabaceae & Leaves \\
4 & Hunteria umbellata (K. Schum) Hallier & Fabaceae & Seeds \\
5 & Senna alata (L.) Roxb. & Fabaceae & Flowers \\
6 & Piper guinense Schumach & Piperaceae & Fruits and leaves \\
7 & Xylopia aethiopica (Dumel) A. Rich. & Annonaceae & Fruits \\
8 & Capsicum frutescens L. & Solanacecae & Fruits \\
9 & Alstonia boonei De Wild. & Apocynaceae & Stem bark \\
10 & Khaya senegalensis A. Juss. & Meliaceae & Stem bark \\
11 & Allium sativum L. & Amaryllidaceae & Leaf base \\
12 & Eugenia aromaticum (L.) Merr. \& & Myrtaceae & Flower buds \\
& L.M. Perry & & \\
13 & Petiveria alliacea L. & Phytolacaceae & Stem bark \\
\hline
\end{tabular}

Herbal recipes for 14 powdered drugs: PILES-A (1, 2), PILES-B ( $3+$ potash), PILES-C ( 4 only), PILES-D $(5,7$ + potash + sulphur), PILES-E $(5,7,12$, + kafura + potash), PILES-F $(3,13$ + suga + potash), PILES-G $(4,7,9)$; PILES-I (5 only), PILES-J (5 only), PILES-K $(3,8)$, PILES-L $(3,10)$ PILES-M (5 + potash), PILES-N $(4,11)$ and PILES-O $(5,7,+$ kafura); suffix alphabets indicate the manufacturers' anonymity codes.

PILES, piles disease.

TABLE 13: Names of plants and their parts used for the formulation of traditional oral powdered herbal formulations for the treatment of typhoid fever in Ogbomoso, Nigeria.

\begin{tabular}{llll}
\hline Number & Plant species name & Family & Part(s) used \\
\hline 1 & Carica papaya L. & Caricaceae & Unripe fruit \\
2 & Piper guinense Schumach. & Piperaceae & Fruits and leaves \\
3 & Alstonia bronei De Wild. & Apocynaceae & Stem bark \\
4 & Allium cepa L. & Amaryllidaceae & Leaves \\
5 & Capsicum frutescens L. & Solanaceae & Fruits \\
6 & Xylopia aethiopica (Dunal) A. Rich. & Annonaceae & Fruits \\
7 & Anthocleista djalonensis A. Chev. & Gentianaceae & Stem bark \\
8 & Morinda lucida Benth. & Rubiaceae & Stem bark \\
9 & Huntaria umbellate K. Schum. & Apocynaceae & Fruit \\
10 & Zingiber officinale Roscoe & Zingiberaceae & Rhizome \\
11 & Mangifera indica L. & Anacardiaceae & Stem bark \\
12 & Zanthoxylum zanthoxyloides (Lam.) & Rutaceae & Stem bark \\
& Zepern. & & \\
13 & Olax subscorpioidea Oliv. & Olacaceae & Root bark \\
14 & Securidaca longipedunculata Fresen. & Polygalaceae & Root \\
15 & Citrillus colocynthis (L.) Schrad. & Cucurbitaceae & Fruit \\
16 & Thonningia sanguine Val. & Balanophoraceae & Bulbs \\
\hline
\end{tabular}

Herbal recipes for 11 powdered drugs: TYPHO-B (1, 2 + palm kernel oil), TYPHO-C $(3,4,5+$ table salt), TYPHO-E $(5,6,7,8,15)$, TYPHO-F $(9+$ alum), TYPHO-G $(3,4,5)$, TYPHO-I (16 only), TYPHO-J ( 3 + potash), TYPHO-K (10 + potash), TYPHO-L (11 only), TYPHO-M (10 + potash) and TYPHO-N $(3,12,13,14)$; suffix alphabets indicate the manufacturers' anonymity codes. TYPHO, typhoid fever.

three species, namely Garcinia kola, Khaya senegalensis and Lophira alata, are categorised as threatened or 'Vulnerable' (VU) species. The status of the other five species is 'Least Concern' (Capsicum frutescens, Persea ameicana, Sorghum bicolor) and 'Data Deficient' (Carica papaya and Mangifera indica) categories.

In formulating the powdered drugs, the THMPs collected or purchased the appropriate herbs fresh, partly dried or dried, and if necessary, they properly dried and mechanically milled it into separate powders. Appropriate proportions of each powder for a drug was determined and used by individual manufacturers to compose the drugs. Lastly, the drug was sieved and stored in containers, ready for sale.

\section{Discussion}

Indications for TOPHFs produced in Ogbomoso, which have been highlighted in this study (Table 2), are a reflection of the prevalence of malaria, piles, typhoid and high blood pressure among the residents of Ogbomoso. On the other hand, ill health conditions such as onchocerciasis, yellow fever, diabetes and internal ulcers appear to be relatively uncommon, or else, the sufferers of these ailments did not seek healing or management from THMPs. There is ample evidence to show that malaria is a major public health problem in Nigeria, accounting for more cases and deaths than any other country in the world (United States Embassy in Nigeria 2011; World Health Organization 2013). The preponderance of antimalarial powdered drugs among the traditional healers in the study area is a confirmation that the disease is prevalent in the southwestern parts of the country (Okunade 2001).

The number of plant species being exploited by the THMPs in Ogbomoso is on the higher side, and this calls for the necessity to examine whether production of these drugs in the area is sustainable, and if the local vegetation will not be put in jeopardy soon. About $44 \%$ of the TOPHF manufacturers sourced their raw material herbs by buying it from the vendors. Truly, a few of the purchased herbs are collections from outside Ogbomoso land; however, a scrutiny of the lists in Tables 3-13 revealed that a good number of them were obtainable in the savanna woodland to which Ogbomoso belongs (Keay 1989). Therefore, there is the probability that most of these plants were readily available in the past for free collection in the neighbourhoods, but now have to be purchased by the users because of urbanisation and other related factors that have rendered them less accessible (Hsueh 2009; Liu et al. 2015). The natural flora of the study area has been largely impacted to the extent that only $28 \%$ of the healers now source their raw materials through collection in the wild.

Information about the quantities of the herbs extracted annually by the TOPHFs manufacturers in Ogbomoso is not available to make categorical statements. However, if it is assumed that 47 of the plant species used for TOHPFs not yet evaluated by the IUCN are not threatened, it is logical to infer from available data from this study and information in the red list of IUCN that production of TOPHFs in the study area is sustainable. In addition, the activities of these traditional drug manufacturers do not, at the moment, appear to pose any threat to the population of these plant species, inasmuch as the herbs from the plants (i.e. stem barks and seeds) can be extracted sustainably. Efforts made by certain THMPs (28.1\%) in cultivating some of the plant species they use are also commendable, but there is room for improvement.

\section{Conclusion and recommendation}

Sixty-eight TOPHFs manufactured in Ogbomoso are indicated for the treatment of 17 different kinds of health conditions, including malaria, piles and typhoid, and in the management 
of such dreaded diseases as high blood pressure, yellow fever and diabetes. Herbs from members of 33 angiosperm families are exploited to produce these drugs, but this practice is considered sustainable with minimal injury to the neighbouring flora as long as sustainable harvesting can be encouraged or enforced along with medicinal plants cultivation.

\section{Acknowledgements}

The authors are thankful to the THMPs in Ogbomoso who wilfully divulged vital information about the powdered herbal formulations reported.

\section{Competing interests}

The authors declare that they have no financial or personal relationships which may have inappropriately influenced them in writing this article.

\section{Authors' contributions}

J.E.I. was responsible for data collection and preparation of the draft manuscript. A.T.J.O. was responsible for conceptualisation of research and manuscript preparation. M.A.J. performed data collection and collation.

\section{References}

ABFR \& CO, 1996, Chronology of Nigerian decrees, ABFR \& Co Law Office, Onikan, Lagos, viewed 01 August 2018, from http://www.abfr\&co.com/1992n.htm.

Bauer, R., 1998, 'Quality criteria and standardization of phytopharmaceuticals: Can acceptable drug standards be achieved?', Drug Information Journal 32, 101-110. https://doi.org/10.1177/009286159803200114

Chen, S., Yu, H., Luo, H., Wu, Q., Li, C. \& Steinmetz, A., 2016, 'Conservation and sustainable use of medicinal plants: Problems, progress and prospects', Chinese Medicine 11, 37. https://doi.org/10.1186/s13020-016-0108-7

Hsueh, D., 2009, 'New York City's metropolitan dome: Past and present $\mathrm{CO}_{2}$ concentration patterns from an urban to rural gradient', Unpublished M.A. thesis, Department of Ecology Evolution and Environmental Biology (E3B), Columbia University.

IUCN, 2017, The IUCN red list of threatened species, International Union for Conservation of Nature, viewed 01 August 2018, from www.iucnredlist.org.
Kadam, P.V., Yadav, K.N., Patel, A.N., Navsare, V.S., Bhilwade, S.K. \& Patil, M.J., 2012, 'Phytopharmacopoeial specifications of Garcinia indica fruit rinds', Pharmacognosy Journal 4(31), 23-28. https://doi.org/10.5530/pj.2012.31.5

Keay, R.W.J., 1989, Trees of Nigeria, Oxford Science Publication, New York, p. 476 ISBN: 0-19-854560-6.

Lau, A.H., Woo, S. \& Koh, H., 2003, 'Analysis of adulterants in a traditional herba medicinal product using liquid chromatography-mass spectroscopy', Journal of Pharmaceutical and Biomedical Analysis 31, 401-406. https://doi.org/10.1016/ S0731-7085(02)00637-4

Liu, Y. Wang, Y., Peng, J., Du, Y., Liu, X., Li, S. et al., 2015, 'Correlations between urbanization and vegetation degradation across the world's metropolises using DMSP/OLS Nighttime Light Data', Remote Sensing 7, 2067-2088. https://doi. org/10.3390/rs70202067

Medicine Hunter, 2012, On sustainability and medicinal plants, viewed 01 August 2018, from www.medicinehunter.com/sustainability.

Obu, R.N., 2015, Challenges facing traditional medicine in Ghana, Feature Article, Modern Ghana, viewed from www.modernghana.com/news/648038/1/challengesfacing-traditional-medicine-inin-ghana.htm.

Ogunkunle, A.T.J \& Ashiru, S.B., 2011, 'Experience and perceptions of the residents of Ogbomoso land Nigeria on the safety and efficacy of herbal medicines', Journal of Herbal Practice and Technology 1, 22-28.

Okunade, A.O., 2001, The underdevelopment of health care system in Nigeria, Faculty of Clinical Sciences and Dentistry, University of Ibadan, Vantage Publishers Limited, Ibadan, Nigeria.

Osunderu, O.A., 2009, 'Sustainable production of traditional medicines in Africa', in E.K. Yanful (ed.), Appropriate technologies for environmental protection in the developing world, pp. 43-51, Springer, Dordrecht

Patwardhan, B., Warude, D., Pushpangadan, P. \& Bhatt, N., 2005, 'Ayurveda and traditional Chinese medicine: A comparative overview', Evidence-Based Complementary and Alternative Medicine 4, 465-473. https://doi.org/10.1093/ ecam/neh140

Pesic, M., 2015, Development of natural product drugs in a sustainable manner, Brie for GSDR 2015, viewed 03 August 2018, from https://sustainabledevelopment. un.org/.

Prasad, V., Rameshi, S.D. Rakesh, S.S., Karita, N.Y \& Manohar, J.P., 2012, 'Pharmacognostic, phytochemicl' and 'physicochemical studies of Mimmusops
elengi Linn Stem Bark (Sapotaceae)', Der Pharmacia Lettre 4(2), 607-613, viewed elengi Linn Stem Bark (Sapotaceae)', Der
from www.scholarsresearchlibrary.com.

United States Embassy in Nigeria, 2011, Nigeria Malaria Fact Sheet, U.S. Embassy in Nigeria, FCT, Abuja, viewed 30 July 2018 , from http://nigeria.embassy.
gov; http://photos.state.gov/libraries/231771/public/December-MalariaFact gov; http://ph

World Health Organization, 1998, Quality control methods for medicinal plant materials, World Health Organization, Geneva.

World Health Organization, 2000, General guidelines for methodologies on research and evaluation of traditional medicine, World Health Organization, Geneva.

World Health Organization, 2002, General guidelines for methodologies on research and evaluation of traditional medicine, World Health Organization, Geneva.

World Health Organization, 2003, WHO guidelines on good agricultural and collection practices (GACP) for medicinal plants, WHO, Geneva.

World Health Organization, 2013, Malaria Fact sheets, World Health Organization viewed 30 July 2018, from http://www.who.int/mediacentre/factsheets/fs094/en/. 